\title{
HUBUNGAN LAMANYA MENSTRUASI DENGAN KADAR HAEMOGLOBIN PADA MAHASISWI POLITEKNIK KESEHATAN KEMENKES BANTEN
}

*Parta Suhanda, *Suyatini

\begin{abstract}
ABSTRAK
Latar belakang :. Proses menstruasi merupakan kondisi normal yang dialami wanita setelah masuk masa pubertas, prosess ini apabila berlangsung tidak normal akan berpengaruh pada kadar hemoglobin, banyak faktor yang mempengaruhi $\mathrm{Hb}$ dimana kadar $\mathrm{Hb}$ yang rendah akan mempengaruhi banyak faktor diantaranya prestasi belajar menurun karena anemia. Tujuan penelitian : mengetahui apakah ada hubungan lamanya menstruasi dengan kadar $\mathrm{Hb}$ pada mahasiswi Poltekkes Kemenkes Banten. Metodologi penelitian : Penelitian ini menggunakan desain pre post desain dengan mengukur lamanya menstruasi dihubungkan dengan kadar $\mathrm{Hb}$ setelah menstruasi, sampel sebanyak 35 responden dan diukur kadar $\mathrm{Hb}$ dengan metode auto analizar. Hasil penelitian : Rerata lamanya menstruasi 6 hari dengan rentang $3-8$ hari, rerata kadar haemoglobin sebelum $12.67 \mathrm{~g} / \mathrm{dl}$, dan setelah $12.06 \mathrm{~g} / \mathrm{dl}$. Hasil uji statistik koefisien korelasi (r=-0.12) hubungan lemah, dengan pola hubungan negatif dan nilai $(\mathrm{p}=0.492)$ tidak ada hubungan yang bermakna antara lamanya menstruasi dengan kadar haemoglobin. Kadar $\mathrm{Hb}$ pada penelitian ini tidak dipengaruhi oleh lamanya menstruasi, dimungkinkan dipengaruhi oleh faktor lain. Seperti asupan makanan, kondisi sumsum tulang tulang dll. Kesimpulan : Tidak ada hubungan yang bermakna antara lamanya menstruasi dengan kadar $\mathrm{Hb}$, pola hubungan negatif.
\end{abstract}

Kata Kunci : Menstruasi, kadar Hb

*Poltekkes Kemenkes Banten 


\section{Pendahuluan}

Wanita dewasa sehat dan tidak hamil setiap bulan secara teratur akan mengalami proses menstruasi (haid). Siklus menstruasi ini, selaput lender rahim dari hari ke hari terjadi perubahan yang berulang selama satu bulan mengalami empat masa (stadium). ${ }^{1}$

Pada siklus menstruasi, diperkirakan seorang wanita akan kehilangan rata-rata kurang dari $60 \mathrm{~mL}$ darah. Salah satu komposisi bahan yang terkandung dalam darah yang keluar melalui siklus menstruasi adalah zat besi dan diperkirakan sebanyak 0,5-0,7 mg zat besi dieksresikan per hari. Penurunan jumlah zat besi di dalam tubuh melalui proses menstruasi yang fisiologis sedikit banyak akan mempengaruhi konsentrasi hemoglobin dalam tubuh seseorang. Konsentrasi hemoglobin diukur dalam unit gram per desiliter (g/dL). Nilai normal konsentrasi hemoglobin pada setiap wanita dewasa normal adalah 12-16 g/dL.

Menurut penelitian Al-Sayes pada Tahun 2011, kehilangan darah yang banyak pada wanita merupakan faktor resiko penting yang dapat menyebabkan anemia defisiensi besi pada wanita. Zat besi akan keluar sebanyak kurang lebih 42 mg setiap siklus menstruasi. Sedangkan pada wanita yang tidak sedang menstruasi akan kehilangan zat besi sebesar $1 \mathrm{mg}$ per harinya. Dari data primer dapat dilihat bahwa remaja dengan menstruasi 8 hari memiliki kadar hemoglobin rata-rata 11,1 g/dl sedangkan remaja dengan lama menstruasi 9 hari memiliki kadar hemoglobin 9,8 g/dl. Sehingga dapat disimpulkan kehilangan zat besi yang berkelanjutan pada wanita menstruasi akan memperbesar faktor resiko wanita tersebut mengalami anemia

\section{Metoda}

Penelitian ini menggunakan desain penelitian pre dan post tes, yaitu responden di ukur kadar $\mathrm{Hb}$ satu hari sebelum menstruasi dan diukur lagi setelah selesai menstruasi. Diukur lamanya/waktu menstruasi dihubungkan dnegan kadar hemoglobin setelah selesai menstruasi. Penelitian menggunakan tipe onegroup design dengan pre dan post test. Sampel dalam penelitian ini berjumlah 35 mahasiswa politeknik kemenkes Banten.

Analisis data dalam penelitian ini diolah dengan program statistik. Analisa univariat dilakukan untuk mendeskripsikan karakteristik dari masing-masing variabel yang di teliti. Hasil analisa data berupa distribusi frekwensi dan presentasi dari masing-masing variabel yang meliputi mean, median dan standar deviasi. 
Analisa bivariat dilakukan untuk membuktikan hipotesa yang telah dirumuskan dengan uji hubunga (korelasi) untuk mengetahui kekuatan hubungan antara lamanya menstruasi dengan kadar $\mathrm{Hb}$ setelah menstruasi.

\section{Hasil}

Selama pengumpulan data yang dilakukan mulai bulan Mei sampai Agustus 2015.

Jumlah responden penelitian sebanyak 35 responden.

\section{Tabel 1}

Rerata Kadar Hb sebelum Menstruasi Pada mahasiswa Poltekkes Banten Tahun 2015

\begin{tabular}{|c|c|c|c|c|}
\hline Variabel & Mean & $\begin{array}{c}\text { Min- } \\
\text { Max }\end{array}$ & $95 \%$ CI & SD \\
\hline $\begin{array}{c}\text { Kadar } \\
\mathrm{Hb}\end{array}$ & 12.76 & $\begin{array}{c}10.70- \\
14.80\end{array}$ & $\begin{array}{c}12.3997 \\
-\end{array}$ & 1.04886 \\
13.1203 & \\
\hline
\end{tabular}

Tabel 1. menunjukkan Dari 35 responden rata-rata kadar $\mathrm{Hb}$ sebelum mentruasi adalah 12.76 gram/dl dengan 95\%CI : 12.3997 - 13.1203 dan SD 1.04886 gram/ dl. Kadar $\mathrm{Hb}$ terendah adalah $10.7 \mathrm{~g} / \mathrm{dl}$ dan Kadar $\mathrm{Hb}$ tertinggi adalah 14.80 g/dl.

\section{Tabel 4.2}

Rerata kadar Hb setelah Menstruasi mahasiswa Poltekkes Banten Tahun 2015

\begin{tabular}{|c|c|c|c|c|}
\hline Variabel & Mean & Min-Max & $95 \%$ CI & SD \\
\hline Kadar Hb & 12.06 & $9.60-13.90$ & $11.72-12.41$ & 1.009 \\
\hline
\end{tabular}

Dari 35 responden rata-rata kadar $\mathrm{Hb}$ setelah mentruasi adalah $12.06 \mathrm{gram} / \mathrm{dl}$ dengan 95\%CI : $11.7190-12.4124$ dan SD 1.00935 gram/ dl. Kadar $\mathrm{Hb}$ terendah adalah $9.60 \mathrm{~g} / \mathrm{dl}$ dan Kadar Hb tertinggi adalah $13.90 \mathrm{~g} / \mathrm{dl}$

\section{Diagram 4.1}

Rerata Kadar Haemoglobin $(\mathrm{Hb})$

Mahasiswi Politeknik Kesehatan

Kemenkes Banten Sebelum dan Setelah Menstruasi

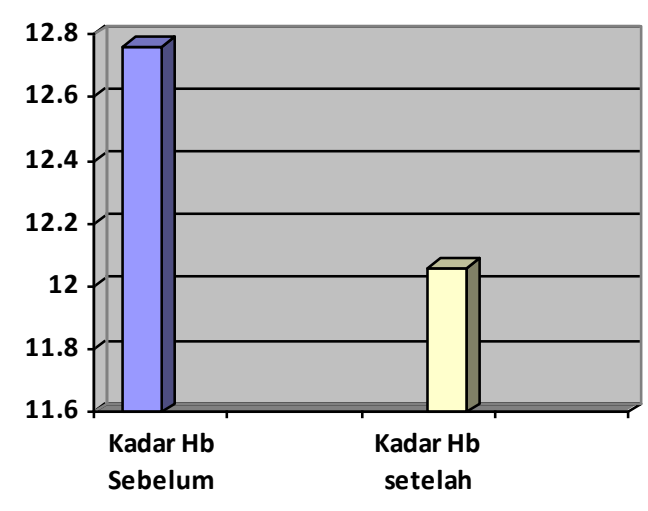

Tabel 4

Rerata lamanya Menstruasi Mahasiswa Poltekkes Banten Tahun 2015

\begin{tabular}{|c|c|c|c|c|}
\hline Variabel & Mean & $\begin{array}{c}\text { Min- } \\
\text { Max }\end{array}$ & $95 \%$ CI & SD \\
\hline $\begin{array}{c}\text { Lama } \\
\text { Menstruasi }\end{array}$ & 6.11 & $3-8$ & $\begin{array}{c}5.68- \\
6.55\end{array}$ & 1.278 \\
\hline
\end{tabular}

Dari 35 responden rata-rata lamanya mentruasi responden adalah 6 hari dengan 95\%CI : 5.68 - 6.55 dan SD 1.278 hari. Lamanya menstruasi paling pendek 3 hari. paling lama 8 hari.

Tabel 4

Hasil Uji Statistik Hubungan lamanya menstruasi dan Kadar Haemoglobin setelah Menstruasi tahun 2015

\begin{tabular}{|l|c|c|}
\hline \multicolumn{1}{|c|}{ Variabel } & $\mathrm{R}$ & Nilai P \\
\hline $\begin{array}{l}\text { Lamanya Menstruasi } \\
\text { Kadar Hb setelah } \\
\text { Menstruasi }\end{array}$ & -0.120 & 0.492 \\
\hline
\end{tabular}

Dari tabel 4 di atas terlihat bahwa lamanya menstruasi dengan Kadar $\mathrm{Hb}$ mempunyai koefisien korelasi (r) -0.120. Dimana 
hubungan tersebut dapat dikategorikan lemah yang berpola negatif artinya semakin lama menstruasi maka kadar $\mathrm{Hb}$ semakin menurun. Dari uji statistik di peroleh nilai $\mathrm{P}$ 0,492 dengan demikian secara statistik pada taraf kepercayaan 5\% tidak terdapat hubungan yang bermakna antara lamanya menstruasi dengan kadar $\mathrm{Hb}$ pada mahasiswa Poltekkes Banten tahun 2015.

\section{Pembahasan}

Penelitian ini dilakukan untuk mengetahui hubungan lamanya menstruasi degan Kadar Hemoglobin. Metode pemeriksaan yang digunakan dalam penelitian ini adalah dengan menggunakan alat otomatis hematologi analyzer $(\mathrm{POCH}$ 100i).

Hasil penelitian ini menunjukan bahwa rerata lamnaya menstruasi 6 hari dengan rentang lamnaya menstruasi 3 hari sampai 8 hari. Kondisi ini menujukan bahwa lamanya proses menstruasi ada pada rentang normal (3-5/7-8 hari) Kadar hemoglobin pada saat sesudah menstruasi lebih rendah dibandingkan dengan kadar hemoglobin sebelum menstruasi (12.76 sebelum dan 12.06 setelah).

Hal ini juga diperoleh pada penelitian yang dilakukan oleh Hardhianti Ayu Mustika Sari (2011). Penurunan kadar hemoglobin ini wajar terjadi karena saat menstruasi terjadi kehilangan darah. Penurunan jumlah ferum didalam tubuh melalui proses menstruasi yang fisiologis ini sedikit banyaknya akan memperngaruhi kadar hemoglobin dalam tubuh. ${ }^{16}$ Selain kadar $\mathrm{Hb}$ dipengaruhi oleh beberapa factor diantaranya faktor respon sumsum tulang, faktor berat badan seseorang, faktor asupan konsumsi makanan, faktor menstruasi yang lebih cepat dibanding yang mengalami penurunan kadar hemoglobin. Menstruasi yang berlebihan merupakan penyebab defisiensi besi pada wanita. Salah sautnya disebabkan oleh penurunan nafsu makan sehingga asupan zat-zat yang diperlukan oleh tubuh berkurang misalnya zat besi, dan asam amino, oleh karena itu diperlukan makanan yang bergizi setiap hari. $^{17}$

Berdasarkan penelitian yang telah dilakukan, rata-rata kadar hemoglobin saat sebelum menstruasi yang didapat dari sampel penelitian adalah 12,7 g/dL . Serta rata-rata kadar hemoglobin saat sesudah menstruasi yang didapat dari sampel penelitian adalah $12,1 \mathrm{~g} / \mathrm{dL}$. Nilai yang didapat ini termasuk kategori normal menurut WHO (World Health Organization). Dari nilai rata-rata yang didapat saat sebelum dan sesudah menstruasi menunjukan penurunan kadar hemoglobin saat sebelum hingga sesudah menstruasi. Serta terjadi peningkatan dua 
kali lipat sampel penelitian yang mengalami anemia ringan saat sesudah menstruasi dibandingkan saat sebelum menstruasi yaitu $40 \%$ berbanding $20 \%$ saat sebelum menstruasi. Hal ini disebabkan karena setelah mengalami perdarahan yang cepat maka tubuh akan menggantikan dalam lama waktu 1-3 hari, akibatnya konsentrasi sel darah merah akan menurun. Pada kehilangan darah yang kronis, penderita sering kali tidak dapat mengabsorbsi cukup besi dari usus halus untuk membentuk hemoglobin secepat darah yang hilang sehingga sel darah merah yang terbentuk itu mengandung sedikit hemoglobin. Kadar hemoglobin rendah bisanya tidak selalu merupakan tanda atau gejala penyakit. Ini mungkin normal bagi sebagian orang. Wanita yang menstruasinya terlalu lama biasanya mengalami kadar hemoglobin rendah karena terjadi penurunan ferum dalam tubuh melalui proses menstruasi. Kekurangan kadar hemoglobin yang hanya sedikit lebih rendah dari kadar hemoglobin normal, tidak dianggap berbahaya dan tidak menimbulkan gejala. ${ }^{18}$

Pada tabel 4 di atas terlihat bahwa lamanya menstruasi dengan Kadar $\mathrm{Hb}$ mempunyai koefisien korelasi (r) -0.120. Dimana hubungan tersebut dapat dikategorikan lemah yang berpola negatif artinya semakin lama menstruasi maka kadar $\mathrm{Hb}$ semakin menurun. Dari uji statistik di peroleh nilai $\mathrm{P}$ 0,492 dengan demikian secara statistik pada taraf kepercayaan 5\% tidak terdapat hubungan yang bermakna antara lamanya menstruasi dengan kadar $\mathrm{Hb}$ pada mahasiswa Poltekkes Banten tahun 2015.

\section{Simpulan}

Hubungan lamanya menstruasi dengan Kadar $\mathrm{Hb}$ mempunyai koefisien korelasi (r) -0.120. Dimana hubungan tersebut dapat dikategorikan lemah yang berpola negatif artinya semakin lama menstruasi maka kadar $\mathrm{Hb}$ semakin menurun. Dan hasil uji statistik di peroleh nilai P 0,492 dengan demikian secara statistik pada taraf kepercayaan 5\% tidak terdapat hubungan yang bermakna antara lamanya menstruasi dengan kadar $\mathrm{Hb}$ pada mahasiswa Poltekkes Banten tahun 2015.

\section{Daftar Pustakaan}

1. Wahyuni Pradyptasari. dkk. 2013 "Hubungan Konsumsi Makanan Mengandung Fitoestrogen dengan Siklus Menstruasi pada Siswi Kelas X SMAN 21 Makasar" Program Studi Ilmu Gizi. Fakultas Kesehatan Masyarakat. Universitas Hasanudin. Makasar.

2. Prastika Dewi. A. 2011. "Hubungan Lama Menstruasi Terhadap Kadar Hemoglobin pada Remaja Siswi SMAN 1 Wonosari" KTI. Program Studi DIV Kebidanan. Fakultas Kedokteran. Universitas Sebelas Maret. Surakarta. 
3. Sari. Hardhianti Ayu Mustika. 2011. "Perbedaan Kadar Hb 2 Hari Sebelum Menstruasi dan 2 Hari Setelah Menstruasi” KTI. Program Studi D3 Analis Fakultas Ilmu Kesehatan Universitas Muhammadiyah Surabaya.

4. Hoffbrand A. V. dkk. 2012. "Kapita Selekta Hematologi Edisi 4". Penerbit Buku Kedokteran EGC. Jakarta.

5. Puspita Ratna. "Mengukur Kadar Hemoglobin Sebelum dan Sesudah Menstruasi Berdasarkan Lamanya Siklus Menstruasi pada Siswi SMPN 7 Semarang". Universitas Muhamadiyah Semarang. Semarang.

6. Yamin Tentri. 2012. "Hubungan Pengetahuan. Asupan Gizi dan Faktor Lain yang Berhubungan dengan Kejadian Anemia pada Remaja Putri di SMA Kabupaten Kepulauan Selayar". Skripsi. Fakultas Kesehatan Masyarakat Peminatakan Kebidanan Komunitas . Universitas Indonesia. Depok.

7. Chandranita. Ayu. dkk. 2009. “ Memahami Kesehatan Reprouksi Wanita Ed. 2". Penerbit Buku Kedokteran EGC. Jakarta.

8. Heffner. Linda J. dkk. "At a Glance Sistem Reproduksi Edisi Kedua". Erlangga Medical Series. Jakarta.

9. Jeniawaty. Sherly. Dkk. 2008. "Peningkatan Kadar Hemoglobin Wanita Usia Subur Dengan Tablet Tamba Darah Sewaktu Menstruasi”. Jurnal Penelitian Politeknik Kesehatan Depkes Surabaya 